\title{
Reimagining Democracy through Syria's Wartime Sharia Committees
}

\author{
Emma Findlen LeBlanc
}

\begin{abstract}
This article examines Syrians' narratives about the network of Sharia Committees (Hay'ät al-Sharia) that emerged as the most pervasive and popular legal project during the ongoing civil war. Many Syrians formerly excluded from political power, especially working-class Sunnis, envision the Sharia Committees as a revolutionary space for realising self-determination, where sharia is articulated as a democratic legal process embedded in its ostensibly inherent pluralism, flexibility, anti-authoritarianism and conception of justice as reconciliation and public good. By reviving a historically recurrent vision of sharia as radical democratic practice, Syrians attempt to extricate sharia from its entanglements with efforts to govern. The Sharia Committees thus represent a creative effort to reclaim democracy from state control while challenging rigid, rule-oriented understandings of sharia.
\end{abstract}

Keywords: democracy, Hay'ät al-Sharia, Islam, law, sharia, Syria

\section{Beyond Croissant Bans and Severed Hands}

Since the second year of the popular-uprising-turned-civil-war in Syria, the conflict has increasingly come to be framed in a similar rhetoric to that promoted by the Syrian al-Assad regime since the beginning of the revolt in 2011: as a struggle between a secular, modern (even if, we collectively concede, tyrannical) government and a violent, uncontrollable, Islamist rabble. Although the war in Syria is defined by its fragmented participants in terms of many goals, over the past several years it has become increasingly overtly Islamic and sectarian. The concept of sharia, popularly glossed as Islamic law, has come to symbolise the opposition of Islam to Western politics and morality, 
a contrast that acts as a claim to legitimacy for Islamist fighting groups, and is perceived as a threat by the West. Sharia has come to be associated in the global popular imagination with its most extreme, sensational (if rare) manifestations: stoning adulterers, chopping the hands off thieves, and even the forcible veiling of women, the latter of which has particularly shaky scriptural foundations, but serves well the old orientalist, imperialist legitimating rhetoric that justifies Western domination as 'white men saving brown women from brown men' (Spivak 1988: 297). Even before the emergence of ISIS, ${ }^{1}$ popular media tended to present sharia in Syria as a threat, evoking the specter of 'jihadi justice' - chaotic, arbitrary and violent - nowhere, perhaps, more titillatingly crafted to trivialise Islam and arouse Western bourgeois anxieties than in The Times's headline 'Croissants Outlawed Under Syrian Rebels' Sharia Law' (Blanford 2013).

This article will examine what it is that we really talk about when we talk about sharia and democracy in Syria, analysing Syrians' depictions of local Sharia Committees (Hay'ät al-Sharia) as flexible spaces in which they are creatively reimagining justice, community and the collective moral order, in ways that challenge conventional assumptions about law and the nation-state. The Sharia Committees are a decentralised network of local legal councils, administered by village and neighbourhood leaders, which apply a variety of different sharias interpreted through local custom. At the time of my research, in 2013, they were the most widespread and popular legal project in Syria, operating throughout rebel-controlled territory, and even in some areas nominally under regime control. ${ }^{2}$ The vision of Islam and democracy articulated by most of my working-class, Sunni informants, and embodied for them in the ideal of the Sharia Committees, is one in which democracy is achieved through Islam, as a social, political and legal practice. And if Islam is the answer to democracy, the most promising strategy for its fulfilment, democracy is also their answer to Islam, the collective practice through which authoritarian trends in Islam are thwarted, and its true radical vision for justice realised.

This article is based primarily on interviews conducted between June and September 2013 in southeastern Turkey and Istanbul with approximately 65 Syrian activists, politicians, lawyers, judges, tribal sheikhs, Islamic leaders, fighters and working-class refugees who were male and female, rural and urban, young and old, and unallied with any legal or political project. I also draw upon my observations from Damascus and Sahnaya, where I lived between 2007 and 2012, including the first year and a half of the revolution. My analysis of the themes and values that emerged as a relatively shared vision of sharia among my informants is not intended to present this vision as homogeneous or uncontested but simply as recurrent, persistent and widespread. Given the methodological limitations of this research, which precluded firsthand observation of legal proceedings and hindered my ability to satisfactorily verify much of the information I received, the conclusions presented here are tentative, suggestive and offered simply as a provocation to approach Syrian 
negotiations over law from a perspective grounded in local understandings of justice.

This research is intended less as a story about Syria's emergent legal practices than as a story about the stories people tell about them. My informants' narratives about justice, pluralism, self-determination and democracy should not be accepted as objective, or even always accurate, depictions of the actual operations of the Sharia Committees. However, their narratives provide valuable insights into how Syrians are imagining justice and the legal-moral order. The successes they cite, the procedures they praise, the concepts of justice they elaborate, speak to an emergent ideal of society. This, then, is an ethnography of a vision.

According to the dominant secularist narrative, the Sharia Committees represent chaos, backwardness and an existential threat: to secularism, to democracy, to tolerance, to law itself and even to the Syrian nation-state. Syrian secularists, especially the elite activists whose voices tend to prevail in policy making, dismiss sharia as local custom, and thus inimical to civilisation, modernity and sophistication. For them, "law is the instrument of civilization' (Merry 1988: 875), as opposed to sharia, which, as one Syrian National Coalition (SNC) politician insisted, 'is something that belongs to an earlier society, which doesn't fit into modern society. It is something meant for a different time and place. To explain the prevalence and popularity of the Sharia Committees, secularists insist that sharia law is a project forced upon Syrians through the threat of violence by foreign Islamist fighters. Conservative Muslim Brotherhood politicians and secular, Syrian American leaders in the SNC alike share the conviction that Syrians go to the Sharia Committees because they are 'forced by militias'. The coercion is structural, too; according to Inas, ${ }^{3}$ a Syrian activist working for a European-funded NGO in Turkey, Syrians use the Sharia Committees only 'because there is no alternative court. If you had an alternative, of course they would want to go there'. Among the extremely influential Turkey-based opposition activist corps, which tends to be upper-class, highlyand foreign-educated, cosmopolitan and English-speaking, an elitist bias often emerges in their assessments of the working-class gravitation towards Islam. When pushed to account for the strength of the Sharia Committees even in areas controlled by secular fighting groups, or in neighbourhoods still under regime control, they concede that most Syrians think that they want sharia, but democracy is better for them, they just don't know it. Sharia and democracy are consistently juxtaposed in this discourse. These elites see themselves as the guardians of an ignorant, credulous population too easily manipulated by fiery Islamic rhetoric, or, as one Western commentator suggests, by Islamists' free candy and fun tug-of-war competitions (Zelin 2013).

While it is undoubtedly important to examine the mechanisms in Syria of power and coercion, the secularist rhetoric is challenged by the shared narrative my informants recount about the history of the development of the sharia courts, which asserts a more determined, intentional effort by Syrian 
people to construct Islamic legal spaces. The elite narrative treats 'normal' (' $\bar{a} d \bar{\imath})$ Syrians as passive, 'simple' (basiț ), gullible recipients of Islam, ignoring the creative ways in which they assert their own interpretations of sharia, even against those advocated by Islamic scholars and Islamist politicians. Most Syrians I interviewed - including Bedouin tribal leaders who felt their own power threatened by the Sharia Committees, and atheist, communist Kurdish fighters who granted no particular religious weight to sharia - spoke of the Sharia Committees as spaces of 'justice' ('adäla), and described them as 'successful' (nājih).

The pervasive dichotomisation of sharia and democracy is produced through what David Graeber (2007) describes as a popular misrepresentation of democracy, which identifies democracy with certain kinds of institutions and political structures - such as elections and parliaments - that are actually directed towards containing and controlling the masses, rather than the messier, emergent, localised processes of self-determination that represent genuine democracy. Graeber explains this intentional obfuscation, whereby elites legitimise their rule by claiming to represent the people, while doing their very best to minimise the actual power of the people (2007: 367), as the replacement of democracy as a 'form of governance (a mode of communal self-organization)' with the less democratic, often downright anti-democratic, practice of democracy as a 'form of government (one particular way of organizing a state apparatus)' (2007: 329, emphasis mine). Laura Nader calls upon us to question Western projects of legal imperialism, asking 'what Western ideals, whose model of democracy, why democracy? In whose interest?' (2009: 59). Graeber dismantles our dominant genealogical narrative of democracy, arguing that the democracy we so often trace back through the history of the West, all the way to Athens, is more accurately understood as republicanism, and has always been grounded in a skepticism - even fear and horror - regarding the masses and their political empowerment. Real democracy, he advocates, is found in rural communities in Africa and Brazil, on pirate ships and among Zapatistas, in 'all the places where communities manage their own affairs through an open and relatively egalitarian process of public discussion' (2007: 331).

Graeber's description of the perversion of the democratic process, whereby "the people" must be evoked as the authority behind the allocation of violence, despite the fact that any suggestion that the proceedings be in any way democratized is likely to be greeted with horror by all concerned' (2007:367), is an apt description of the elite secularist project in Syria, which, like Plato's, Aristotle's and Hobbes's philosophies, treats the law as a restraining force against the people (Tamanaha 2004). Graeber's analysis suggests we might even consider the sensational and disturbing depictions of sharia in Syria - the 'cutting off hands' narrative, largely perpetuated by the elite secularists who oppose sharia - as a technique of undermining democracy by cultivating a collective uneasiness about the masses, depicted as dangerous, violent and capricious. The Syrian secularist monopoly on claims to democracy disguises aspirations 
to power as aspirations to participatory self-governance, and obscures the democratic processes envisioned in the Sharia Committees. If democracy is fundamentally about 'ordinary people collectively managing their own affairs' (Graeber 2007: 329), then Syria's Sharia Committees, as local experiments in self-governance, contain radical democratic potential.

\section{Imagining Sharia as Radical Democracy}

Exploring the democratic possibilities envisioned within the Sharia Committees not only helps reorient our discussions about law and justice in Syria, but also provides a new perspective from which to engage long-standing debates about the nature of Islamic law. The Sharia Committees are good to think with, good to think about democracy with, in ways that have urgent and profound consequences for the kinds of governance that Syrians might develop in a future postwar state. The entanglements of sharia and democracy in Syria also suggest new and rewarding ways to approach sharia. Historically, scholars of Islamic law have tended to align themselves with one of two perspectives: Islamic law as fundamentally rigid and static (Masud et al. 2006: 4), or Islamic law as arbitrary and anarchic. Jedidiah Kroncke cites Weber's description of 'kadijustiz' (1968) as the source of these persistent positions, arguing that 'Weber's characterization of Islamic law as dysfunctionally oscillating between theoretical immutability and practical chaos has remained relatively undisturbed in the study of Islamic law' (2005: 47). Kroncke argues that this legal orientalism characterises most Western approaches to Islamic law, epitomised by two of the most prominent scholars, Lawrence Rosen and Joseph Schacht: 'Rosen exploring the injustice born out of total whimsical substantive irrationality and Schacht exploring the injustice born of a totally mercilessly formal and inflexible substantive rationality' (ibid.: 63). These contradictory understandings are in no small part the product of messy definitions, for Islamic law is both regarded as a vast scholarly tradition and as a practice that has taken extremely diverse forms in different cultural and historical contexts. In order to make claims about Islamic law that surmount its unwieldy fluidity, it becomes so narrowly defined as to exclude most ethnographic examples, which must then be dismissed as not really Islamic law (Masud et al. 2006: 4), or so broadly defined as to implode, an 'essentially contested concept' (Starrett 2010: 628), which produces the rather unsatisfying conclusion that 'there are as many Islams as there are situations that sustain it' (al-Azmeh 1993: 1).

While many contemporary scholars of Islam have sought to move beyond the morass of 'kadijustiz', their anti-orientalist efforts to redeem Islam often lead to the kind of equally unhelpful overemphasis on the similarities between Euro-American law and Islamic law to which Kroncke succumbs. While it is certainly worth noting parallels in Islamic law and Euro-American law, such as the similarities between ideals of equity and of șulh (reconciliation) (Makdisi 
1985), this scholarly eagerness to force Islam into the model of Western law fundamentally denies Islamic law legitimacy on its own terms. Fernanda Pirie (2013), Martin Chanock (1985) and Simon Roberts (2005) all caution against universalising secular Western legal language in a way that 'effaces the rationalities of [non-Western legal practices], which involve a different orientation to the normative repertoire, different forms of decision-making, and different relations of power and trust' (Pirie 2013: 51).

Syrian Sharia Committees articulate a vision of law constructed around a fundamental pluralism, localism and popularism. Participants regard the committees not as a mechanism for applying a preconceived set of rules for behaviour, but rather as a structured process of negotiating self-determination. But sharia is not simply the clever label they have given to the makeshift operations of local justice in order to claim moral legitimacy by situating them within a 'great tradition' (Dresch 2012: 31). By contextualising my informants' visions of sharia within Islamic legal theory, and highlighting commonalities with disparate, historically situated interpretations of sharia, from seventeenthcentury jurists to modern Egyptian muftis, I argue that the localism, pluralism, flexibility and focus on reconciliation that they idealise are recurrent tendencies in sharia. The contradiction that has proven so vexing to scholars, between sharia's apparent rigidity and flexibility, is the source of its distinctiveness and appeal for my informants. Theirs is not the only definition of sharia - there are those of the state-sanctioned Syrian religious establishment and Salafi fighting groups with which they must contend, as well as the secularist perspective, which does not recognise sharia as law at all. But it is a formulation of sharia with a historical and textual basis, and it is a particularly useful formulation for analysing the intersection of democracy, the state and sharia. Syrians, in reviving a persistent vision of sharia as radical democratic practice, see themselves as extricating sharia from the other forms of law in which it has become entangled. In doing so, they challenge stale contemporary rule-oriented discourses about sharia, and suggest, alongside Graeber (2007: 365), that we must look to the spaces beyond and outside of the state to envision democratic possibility. By defining sharia as a democratic process, 'normal Syrians' - to adopt their self-designation - not only challenge the secularist configuration of law, authority, politics and the state, but also the orthodox Islamic establishment and those Islamist groups whose sharia projects they see as authoritarian and essentially un-Islamic because of their focus on content - Kroncke's 'theoretical immutability' (2005: 47) - rather than process, an open-ended set of guiding principles.

\section{'It's Different, but It's Still a Real System'}

The Sharia Committees my informants described are fundamentally local. Local people choose local leaders as judges, to apply local understandings of 
the law in order to meet local needs. Despite their prevalence, the committees remain decentralised and non-hierarchical, administered by communities themselves, at the neighbourhood or village level, and are not beholden to any higher external authority. Many of my informants emphasised that the Sharia Committees are 'normal ( ' $\bar{a} d \bar{\imath})$ or 'natural' $\left(t a b \bar{\imath}^{(} \bar{\imath}\right)$ because they emerged out of pre-existing informal non-state dispute resolution processes. In the context of a national legal system regarded as corrupt, inefficient and unpredictable, people tried to resolve their disputes through the guidance of local community leaders. Noor, a middle-aged farmer from Raqqa, explained that 'court was the last resort, not the first. Family and tribe would try and sort things out first. In terms of wanting to see justice done, you didn't think justice would be done in a court'. Abdul Hamid, a lawyer, explained how 'civil law was often enacted by the people without going to the courts. It wasn't recorded or written down. Decisions were made informally and locally'. Fayez, also from Raqqa, affirmed, 'Most of the problems in the community were always solved between ourselves, without needing to go to the court. The courts did not deliver justice'. Many of the same mediators, heads of well-respected families and local pious men, have been chosen as judges in the new Sharia Committees.

The local embeddedness of the Sharia Committees is perceived as producing a pluralism particularly well-suited to serving distinct local needs in Syria's diverse communities, whose specific legal requirements are made even more diverse by the chaos of war. While broadly circumscribed and unified by a shared Islamic basis, the Sharia Committees interpret law according to local needs and local moralities. This decentralised, pluralistic system is seen as essentially more democratic, because it doesn't force any community to conform to a law that violates its own sense of justice. Rezan, a Free Syrian Army fighter, explained that in Deir Ezzor the Sharia Committee is administered according to tribal custom rather than more orthodox interpretations of Islam. He described that Islamist groups 'proposed something like that [more orthodox sharia] but the tribes said "no". The tribes said, "Okay, if you see one of our sons has a girlfriend, will you take him back to Abu Kamal and whip him? No, the tribes will deal with it in their way."' For many of my informants, the Islamic basis of the courts is seen as facilitating this necessary pluralism, as Sunni legal orthodoxy encompasses four different legal schools (madhāhib), as well as a great diversity of interpretations within those schools. Arwa explained that in Deir Ezzor, the Sharia Committees apply 'mediumstrength' sharia, while many informants cited the Damascus suburb of Douma as an example of a more conservative community that has chosen to apply more conservative Hanbali law. Abdul Razzaq, a Free Syrian Army fighter, said that his local courts in Deraa are fairly liberal, as is appropriate to the famously lawless population of the Hawran (of which Deraa is part), while in Raqqa their more rigid courts suit their morality. He insisted, against the implicit skepticism of the secularists, 'it's different, but it's still a real system'. 
Many of my informants emphasised the importance of local judges to the success of the Sharia Committees. For them, law is less about abstract rights, and more about community welfare (istișlạh) and reconciliation (șulh). Both șulh and istișläh are principles elaborated extensively in Islamic legal literature, although my lay informants tended to use them more loosely. One informant explained, 'We have something called șulh. We bring the judge, and the judge reconciles between them. He doesn't give a ruling, he tries to make peace. That is religion. Local judges are important because they can better recognise the needs of the community, and are thus better positioned than outsiders to navigate sulh, which demands taking into account individuals' different circumstances. A community requires a judge that 'knows' (Gilsenan 2006: 119), that understands family situations, personalities, reputations, economic pressures and romantic entanglements, enough to distinguish between theft driven by greed and that driven by necessity, to know when violence is justifiable revenge or an unforgivable violation of the social order. There is also a sense among Syrians that a local judge is less corruptible because he is beholden to the community, and any violation of justice on his part will have significant personal consequences. Aziza, a defected judge, explained that local judges are less corrupt because they care more about their reputations, and, as Tiernan Mennen notes of customary court judges in Sudan, those 'who continually advocate for unfair decisions lose credibility among their community' (2010: 239).

According to my informants, the flexibility of this decentralised, sulhoriented local committee system makes it especially permeable to different legal frameworks, and thus not only able to accommodate Syria's diversity but to constantly evolve and keep up with changing needs. While all of the Sharia Committees claim to administer Islamic law, whether they orient themselves towards one specific legal school or draw directly from the Koran and sunna, they also, to different degrees, incorporate other kinds of law: existing Syrian law, international human rights law, the French civil code and especially local customs. As Arwa explained, 'the Sharia Committees take from the old constitution that which is sound, what they think will benefit the people, and they take from the Qur'an and from international constitutions'. Abdul Razzaq, a Free Syrian Army fighter and official in the Deraa Sharia Committee, has attended several Red Cross-sponsored workshops in Jordan organised specifically for Sharia Committee authorities, and he said that through the Red Cross trainings, the local Deraa judges learned of Islamic justifications for cremating rather than burying bodies during war. There were so many bodies in Deraa that people were struggling to bury them. There wasn't enough space, and people were vulnerable to government air strikes when they were out in the cemeteries, parks and gardens digging graves. But through their commitment to sulh, rather than a more rigid adherence to the Islamic prohibition on burning bodies with which they were familiar, they were able to find an openness to incorporate alternative legal perspectives to meet their specific local needs. 


\section{Pluralism, Flexibility and Justice as Șulh}

Most Syrians see their society as fundamentally pluralistic, and in need of a legal system that accommodates that pluralism. While Syrian regime law upholds sectarian pluralism by administering matters of personal status largely the domestic sphere - in special courts for each religious sect, the Syrian Sharia Committee supporters see their national pluralism as more complex, as emerging through the cultural differences between classes, regions, ethnic groups and urban/rural, Bedouin/non-Bedouin distinctions. For the most part, theirs is not an essentialist interpretation of their pluralism; they do not see themselves as bounded groups defined by intrinsic characteristics. Rather, their vision of law assumes a model of culture as emerging from specific shared histories, living situations and personal choices. They identify these cultures with geographically defined communities, where people's moral orientations tend to converge because of shared life experiences and collective histories, and where a shared vision of order must emerge to govern everyday life.

It is the perceived inherent, fundamental pluralism of sharia that makes it an appropriate framework through which to articulate locally embedded legal projects. Wael Hallaq explains:

Islamic law is one of legal pluralism, not only because it acknowledges local custom and takes it into serious account but also because it offers an array of opinions on one and the same set of facts. This pluralism gave Islamic law three of its fundamental features. First, it equipped it with a great deal of flexibility and adaptability in governing drastically varied societies and regions, from Morocco to the Malay Archipelago and from Transoxiana to Somalia. Second, this pluralism was constitutive of an inner juristic structure that allowed substantive law to undergo piecemeal change throughout the centuries, thereby accommodating new developments in social and economic life. Finally, this great multiplicity of legal opinion reflected, over time and space, the endless varieties of societal interests and concerns, particularly those within the common social order. (2012: 59)

As my informants emphasised, this pluralism is institutionalised in the very foundations of Islamic law: in the plurality of madhähib, the expansive and diverse hadith literature, and the space for judicial discretion and creativity in the interpretative practices of consensus and analogy. Among the hadiths are a series of prophetic reports explicitly affirming the centrality of difference of opinion to Islam (Abou El Fadl 2001). Joseph Schacht notes that 'the maxim that disagreement (ikhtiläf) in the community of Muslims was a sign of divine indulgence had already been formulated in the second century of the hijra' (1964: 67). As Haim Gerber explains, 'A multitude of problems, often of a very important nature, remained unresolved in the classical and post-classical periods, and precisely because of the theoretically sacred nature of Islamic law, these disputes became sacred in themselves, and hence ineradicable. These 
disagreements, known as ikhtiläfät, left wide margins of discretion in the hands of muftis and qadis' (1999: 72).

This pluralism is crucial to the operations of istihsān ('seeking the most equitable solution'; Makdisi 1985: 70), istiṣlāh (public utility, 'consideration of public interest', or 'seeking the best solution for the general interest'; ibid.: $70,80)$ and sulh (reconciliation, peace, compromise). Although traditional fiqh literature distinguishes these concepts, my informants tended to equate them, associating reconciliation between individuals with a more general sense of public interest, idealising 'an ideology that seeks to settle a dispute by uncovering its underlying causes; takes into account social relations ramifying beyond the disputants at hand; and places the restoration of amicable social relations above a search for "objective truth"' (Just 1992: 391). Istișläh and istihsān are both recognised as specific strategies of analogical reasoning and thus among the four orthodox sources of Islam law. Lawrence Rosen explains that 'both are forms of legal reasoning by means of analogy, but each incorporates the idea that analogies may be drawn with a clear eye to the social well-being at large rather than to a strict set of logically required results' (1989: 48). Muhammad Amin Ibn 'Abidin, an eighteenth- to nineteenth-century mufti from Damascus, explained that justice in Islam is about 'making the life of the believer easier and as far as possible free from hurt' (Gerber 1999: 111). Hussein Agrama describes a similar sense among Egyptian muftis that their role is to 'facilitate people's affairs (t'mashi umurohom)' (2010: 10), a phrase that was also used by several of my informants to explain the success of the Sharia Committees. Rosen describes Moroccan judges who pursues șulh, reconciliation, as a means of restoring an ideal of public order and justice according to which individuals are able to negotiate social relations:

Asked whether they would subscribe to a principle like that of American law, which says that similar cases ought to be decided similarly, Islamic judges consistently respond by saying that since no two individuals are the same, no two cases are really the same, and that even the same person in a later situation has accumulated a changed set of relationships... Justice lies not in the similarity of result but in the assessment of the totality of one's personhood. (1999: 44)

My informants associated Islam's idealisation of reconciliation and public welfare with its structural pluralism, identifying the space to navigate between legal options as the structural potential that enables jurists to apply the law flexibly to meet individual and community needs.

If the pluralism of sharia allows judges expansive discretion in pursuing harmony based on the specific exigencies of the case at hand, this judicial orientation towards community well-being demands consideration of local custom in defining that well-being. The Syrian Sharia Committees' fundamental embeddedness in local practices, values and relationships, so lauded by my informants, is thus consistent with certain historical formulations of sharia. 
Gerber argues that much of the dynamism of Islamic law originates from its enthusiastic assimilation of custom (1999: 106), an attitude epitomised by the early legal maxim often cited by the seventeenth-century jurist al-Ramli, that 'whatever is dictated by custom is dictated by law' (Gerber 1999: 105). If the restoration of social relationships is the basic goal of Islamic law, jurists must necessarily draw upon custom in order to interpret the sharia in ways that meet community needs.

\section{The State, Democracy and Sharia}

For many of my informants, the 'cultural assemblage we have come to call law' (Roberts 2005: 13) - that is, a centralised, codified, universal legal code backed by the coercive power of a ruling authority - is associated with domination rather than justice. Roberts explains, 'Law is a concomitant of centralising processes, processes that at a certain point resulted in the formation of the nation state' (ibid.). According to Roberts, 'The understandings, practices and institutional forms called into being by the attempt to govern are so distinctive, so different from what went before and continued to survive alongside, that the term 'law' should not be applied to those other forms of dispute resolution (ibid.). Regardless of whether we accept Roberts's specific demarcation of the analytical category 'law', the connection he highlights between law and ruling is crucial to understanding attempts to reconfigure power by reconfiguring law, as in Syria. Throughout much of Africa and Asia, twentieth-century colonial attempts to govern deployed legal reform towards controlling, taxing, monitoring and 'civilising' native populations, and in so doing cultivated new visions for collective identities and moralities. By co-opting local custom (including local interpretations of sharia), which tended, in Chanock's terms, to use 'living principles in flexible and popular disputing practices', colonial authorities transformed custom into the 'authoritarian legalism of the neotraditional customary law' (1985: 238), forcing local practice into rigid forms that violated local understandings of justice. Brian Tamanaha describes the violence that codification entailed:

The basic problem is that local norms and process could not be removed from their original medium without losing their integrity. In many indigenous contexts, rules were not treated as binding dictates, but rather as flexible rules that could be negotiated in the course of resolving disputes. The essence of the customary systems may be said to have lain in their process, but these were displaced, and the flexible principles which had guided them were not fed into a rule-honing and using machine operating in new political circumstances. (2008: 384)

Sharia was thus often 'transformed from a way of representing and manipulating the world into a set of government rules' (Chanock 1985: 47). But, as 
Schacht insists, 'strict Islamic law is by its nature not suitable for codification' (1964: 92). Muhammad Masud and colleagues describe a long-standing antipathy among Islamic authorities towards the compromises required in applying sharia as state law, 'reflected in a number of vivid statements attributed to the Prophet Muhammad, e.g., "a person who is appointed qādīi is slaughtered without a knife" ... and "two out of every three qāḍīs are in hell"' (2006: 11). Observing the enervated remnants of sharia preserved in the personal status courts of many modern Middle Eastern states, Ebrahim Moosa (1999) concludes that Islamic law essentially ceased with colonialism.

Many of the Syrian Sharia Committee enthusiasts I met shared a sense that in the modern world sharia has fundamentally been dismantled and undermined, not only by its marginalisation within the state legal system, but by the ossification of its rules, the formalisation of its processes, its extraction from their daily lives and customs, and the reconfiguration of its authority. For them, the Sharia Committees are an attempt to rediscover sharia, to disentangle its true ethic from those institutions, practices and beliefs that have distorted it. Morgan Clarke explains:

In the modern nation-state, rule is imposed from above and can thus only be realized through 'systemic surveillance, disciplining and punishment' - in short, 'violence. By contrast, historical societies subject to Islamic law were 'largely self-governing', because Islamic law proper was a 'non-state, community-based, bottom-up' (elsewhere, 'grassroots') juridical system, which 'derived its ethical and moral foundations from ... the very social order which it came to serve in the first place' (Hallaq 2009: 364-365, 544, 549). That is, the law was independently formulated by Islamic legal scholars and practitioners in response to popular need and not codified and imposed by a state legislature and executive until the onset of 'modernization'. Whereas Islamic law mediated conflicts and healed society's wounds, the nation-state created and then subjugated the individual citizen (Hallaq 2009: 366). (2012: 114)

For my informants, the sharia they have experienced in the Syrian personal status courts, the sharia proposed by contemporary secularists and even the sharia promulgated by extremist Islamist fighting groups, all of which define sharia as a set of rules, violate the true grassroots nature of sharia. For them, the Sharia Committees serve to extricate sharia from those other legal forms and institutions that have permeated and subsumed it.

Graeber insists that 'states cannot, by their nature, ever truly be democratized. They are, after all, basically ways of organizing violence' (2007: 365). The Syrian Sharia Committees offer one particular historically and culturally situated model of local democratic process outside of state control. Most Syrians, especially my economically and politically marginalised informants, are highly skeptical about the state; for them, the state is associated with repression, the arbitrary exercise of violence, injustice and inequality. For them, as for Graeber, democracy is produced and maintained at the most local level. 


\section{Conclusion}

The visions of democracy, justice and Islam that so many marginalised Syrians articulate in their narratives about the Sharia Committees are an ideal, a compelling ideal, but an ideal abstracted from current practice, and an ideal whose realisation entails serious obstacles. In considering that ideal not only for its insights into a specific understanding of sharia, but also as a political project, we must consider the kinds of power, domination and violence it obscures. As Peter Just notes, 'among anthropologists there is an ancient tradition of portraying the appropriated other ("my people") in rather Rousseauian terms or, at any rate, of finding and accentuating those aspects of the other that we rather wistfully would wish for ourselves' (1992: 405). If this article has tended towards the idealistic, it is because, ultimately, it is a depiction and an analysis of an ideal, and because it is also a political endeavour, an attempt to elaborate and offer a legal possibility on behalf of those who have dreamt it. The critiques of that possibility - of sharia - are ubiquitous, such that this article has not focused on developing them, but rather on articulating an emergent, popular challenge to their narrative. But there are important critiques of the Sharia Committee project, especially regarding the problems of power and sectarianism, that we must examine if we seek to move beyond the ideal to the practical implications of the Sharia Committees as a viable legal future for Syria.

In anthropological depictions of negotiated orders, of legal processes based in mediation rather than adjudication, embedded in local communities rather than enforced by states, we tend to use the rather romantic language of 'harmony'. But, as Chanock (1985) notes, repairing social relations usually means re-establishing the status quo, and insofar as the status quo involves unequal relationships, relationships of violence, the language of 'harmony' obscures acts of domination. If we observe the real operations of power in local dispute resolution, the process of 'maintaining harmony ... loses its patina of egalitarian warmth' (ibid.: 7). Mennen explains, for example, that the popular, relatively successful customary courts in South Sudan are oriented towards 'reconciliation and community harmony ... restoring harmed parties to their previous state' (2010: 241), but in doing so they reify the male dominance over women that constitutes that 'previous state'. Haider Hamoudi, who sees legal pluralism - such as tribal law in Iraq - as both inevitable and often desirable, acknowledges that 'access to justice is often denied to women and minorities in customary tribunals [and] indigenous law tends to preserve existing structural inequalities, privilege members of any given subcommunity over others, and impose costs on broader society' (2014: 4). If the Syrian Sharia Committees seek to repair relationships by upholding local community norms, insofar as those norms disadvantage women vis-à-vis men, youth vis-à-vis elders or the poor vis-à-vis the wealthy, the local empowerment the committees are believed to enable may not be equally distributed amongst community members. 
Although the Sharia Committees are envisioned as fundamentally pluralistic and tolerant, as embracing the different needs and moralities of Syria's different communities, the basic unity they promote, the range of difference they accommodate, is that of Sunni Islam. While the Sharia Committees are not only a sectarian project, responding to difference along several different, intersecting axes, they remain, at their foundations, sectarian. There may be spaces for the articulation of non-Muslims' legal norms within a sharia system, through their accommodation as dhimmis, a special, protected class of non-Muslim citizens, for example. But in Syria, non-Muslims, even nonSunnis, have not been included in Sharia Committee practice, or its theorisation. While a discussion of whether or not a sectarian legal framework is appropriate or desirable for Syria, and whether democracies can ever properly accommodate minority needs, is beyond the ambitions of this article, we must acknowledge that the purported equality and tolerance of the Sharia Committee system is circumscribed by a sectarianism that is, in the context of Syria's religious pluralism, justifiably worrisome to many minorities.

The Syrian Sharia Committees are a creative effort to reground democracy in local practice, to realign law with local moralities and understandings of justice and to challenge authoritarian trends in Islam and state governance. It is still unclear how the Sharia Committees would function if institutionalised as a national legal system in a state context, or practiced alongside a functional state law; how they could accommodate non-Muslims; how they could resolve disputes across communities; how they could protect the interests of less powerful segments of society; and what they would imply for the construction of a unified, national identity. But, with reasonable caution regarding its implementation, the Sharia Committee ideal is a project worth taking seriously, as an emergent reimagining of how Syrians might live together, an alternative, culturally situated strategy of democracy and self-governance.

Emma Findlen LeBlanc received her DPhil in social and cultural anthropology from the University of Oxford as a Rhodes Scholar. She is a New America fellow, a senior researcher at the American Civil Liberties Union of Maine and an adjunct professor at Southern New Hampshire University. Her research focuses on democracy, law, morality and resistance among marginalised populations. She is currently writing a book about how an Acadian forest community in the paradigmatically neoliberal conditions of New Brunswick, Canada, cultivates an anti-capitalist morality and how that dissident regime of values is contained, eroded and politically disarmed.

Email: emmafleblanc@gmail.com. ORCID: 0000-0003-0876-1245. 


\section{Notes}

1. At the time of my research, ISIS had not yet emerged as an important actor in the Syrian civil war. My informants generally considered the Nusra Front the most extreme Islamist faction. The rise and then fall of ISIS has inevitably influenced emergent sharia practices in Syria.

2. The reassertion of regime control over the vast majority of rebel territory has significantly reduced the prevalence of the Sharia Committees.

3. I have changed the names of my informants for their protection.

\section{References}

Abou El Fadl, K. (2001), Speaking in God's Name: Islamic Law, Authority, and Women (Oxford: Oneworld).

Agrama, H.A. (2010), 'Ethics, Tradition, Authority: Toward an Anthropology of the Fatwa', American Ethnologist 37: 2-18, https://doi.org/10.1111/j.1548-1425.2010.01238.x.

al-Azmeh, A. (1993), Islams and Modernities (London: Verso).

Blanford, N. (2013), 'Croissants Outlawed under Syrian Rebels' Sharia Law', The Times (Australia), 2 August.

Chanock, M. (1985), Law, Custom, and Social Order: The Colonial Experience in Malawi and Zambia (Cambridge: Cambridge University Press).

Clarke, M. (2012), 'The Judge as Tragic Hero: Judicial Ethics in Lebanon's Shari'a Courts', American Ethnologist 39: 106-121, https://doi.org/10.1111/j.15481425.2011.01352.x.

Dresch, P. (2012), 'Legalism, Anthropology, and History: A View from Part of Anthropology', in Legalism: Anthropology and History, (ed.) P. Dresch and H. Skoda, (Oxford: Oxford University Press), 1-38.

Gerber, H. (1999), Islamic Law and Culture: 1600-1840 (Leiden: Brill).

Gilsenan, M. (2006), Recognizing Islam: Religion and Society in the Modern Middle East (London: I.B. Tauris).

Graeber, D. (ed.) (2007), 'There Never Was a West: Or, Democracy Emerges from the Spaces in Between', in Possibilities: Essays on Hierarchy, Rebellion, and Desire (Oakland: AK Press), 329-374.

Hallaq, W.B. (2012), The Impossible State: Islam, Politics, and Modernity's Moral Predicament (New York: Columbia University Press).

Hamoudi, H.A. (2014), 'Decolonizing the Centralist Mind: Legal Pluralism and the Rule of Law', in The International Rule of Law Movement: A Crisis of Legitimacy and the Way Forward, (ed.) D. Marshall, (Cambridge, MA: Harvard University Press), $135-165$.

Just, P. (1992), 'Review: History, Power, Ideology, and Culture: Current Directions in the Anthropology of Law', Law and Society Review 26, no. 2: 373-411, https://doi. org/10.2307/3053902. 
Kroncke, J.J. (2005), 'Substantive Irrationalities and Irrational Substantivities: The Flexible Orientalism of Islamic Law', The UCLA Journal of Islamic and Near Eastern Law 39: 41-72.

Makdisi, J. (1985), 'Legal Logic and Equity in Islamic law', The American Journal of Comparative Law 33: 63-92, https://doi.org/10.2307/840118.

Masud, M.K., Peters, R. and Powers, D.S. (eds.) (2006), 'Qadis and Their Courts: An Historical Survey', in Dispensing Justice in Islam: Qadis and Their Judgments, Studies in Islamic Law and Society 22, (ed.) R. Peters and B. Weiss, (Leiden: Brill), 1-46.

Mennen, T. (2010), 'Lessons from Yambio: Legal Pluralism and Customary Justice Reform in Southern Sudan', Hague Journal on the Rule of Law 2, no. 2: 218-252, https://doi.org/10.1017/S1876404510200052.

Merry, S.E. (1988), 'Legal Pluralism', Law and Society Review 22, no. 5: 869-896, https:// doi.org/10.2307/3053638.

Moosa, E. (1999), 'Languages of Change in Islamic Law: Redefining Death in Modernity', in Perspectives on Islamic Law, Justice, and Society, (ed.) R.S. Khare, (Lanham, MD: Rowman \& Littlefield), 161-198.

Nader, L. (2009), 'Law and the Frontiers of Illegalities', in The Power of Law in a Transnational World: Anthropological Enquiries, (ed.) F. von Benda-Beckmann, K. von Benda-Beckmann and A. Griffiths, (New York: Berghahn Books), 54-73.

Pirie, F. (2013), The Anthropology of Law (Oxford: Oxford University Press).

Roberts, S. (2005), 'After Government? On Representing Law without the State', Modern Law Review 68: 1-24, https://doi.org/10.1111/j.1468-2230.2005.00526.x.

Rosen, L. (1989), The Anthropology of Justice: Law as Culture in Islamic Society (Cambridge: Cambridge University Press).

Rosen, L. (1999), 'Justice in Islamic Culture and Law', in Khare, Perspectives on Islamic Law, Justice, and Society, 33-52.

Schacht, J. (1964), An Introduction to Islamic Law (Oxford: University of Oxford Press).

Spivak, G.C. (1988), 'Can the Subaltern Speak?', in Marxism and the Interpretation of Culture, (ed.) C. Nelson and L. Grossberg, (Urbana: University of Illinois Press), 271-313.

Starrett, G. (2010), 'The Varieties of Secular Experience', Comparative Studies in Society and History 52, no. 3: 626-651, https://doi.org/10.1017/S0010417510000332.

Tamanaha, B.Z. (2004), On the Rule of Law: History, Politics, Theory (Cambridge: Cambridge University Press).

Tamanaha, B.Z. (2008), 'Understanding Legal Pluralism: Past to Present, Global to Local', Sydney Law Review 30: 375-411.

Weber, M. (1968), Economy and Society: An Outline of Interpretative Sociology, (eds.) G. Roth and C. Wittich, (trans.) E. Fischoff et al. (Cambridge, MA: Harvard University Press).

Zelin, A.Y. (2013), 'Al-Qaeda in Syria: A Closer Look at ISIS (Part I)', The Washington Institute, 10 September. 